\title{
Handling Of Crime Case Relating To The Land By A Police Investigator
}

\author{
Sigit Prihanto ${ }^{1}$ and Anis Mashdurohatun ${ }^{2}$
}

Abstract. Handling the criminal case related to the land both by investigators, prosecutors and judges must advance the exact seat keperdataannya legal status. The handling of criminal cases the object of land should be done carefully and cautiously through the understanding of the anatomy of the case and from the evidence of civil owned by the parties. It aims to prevent the engineering / coercion case which is basically a pure civil dispute, eventually used as criminal assault. To deal with this phenomenon, law enforcement agencies have issued policies on formulatif / legislation containing about pending examination of crime related / object land. At the level of the Supreme Court there is a Supreme Court Regulation No. 1 of 1956 and the Supreme Court Decision Number 628K / Pid / 1984. At the level of the Attorney General has issued Circular Letter of the Attorney General for General Crimes No. B-230 / E / EJP / 01/2013. While in the police has been no regulatory policies relating thereto. However, in practice the investigators make policies and regulations issued by the Supreme Court and the Attorney General as guidance in handling the criminal case related to the land. It is for the sake of effectiveness and efficiency in the framework of an integrated criminal justice system. While in the police has been no regulatory policies relating thereto. However, in practice the investigators make policies and regulations issued by the Supreme Court and the Attorney General as guidance in handling the criminal case related to the land. It is for the sake of effectiveness and efficiency in the framework of an integrated criminal justice system. While in the police has been no regulatory policies relating thereto. However, in practice the investigators make policies and regulations issued by the Supreme Court and the Attorney General as guidance in handling the criminal case related to the land. It is for the sake of effectiveness and efficiency in the framework of an integrated criminal justice system.

Keywords: Offense; Land; Police.

\section{Introduction}

The existence of land is one of the basic human needs that affect human life. Of land rights have a strategic role in society. Increasing the number of residents, also increase the demand for land. Thus, it will be increasingly important position of land rights in the society. Because of its strategic land rights, the existence of land and buildings have a higher economic value. Due to the higher economic value of land and buildings, hence increasing the likelihood of negative effects of the emergence of disputes whose object land.

Dispute / disputes / conflict over land can be interpreted as a conflict that was born as a result of the relationship between people or groups on issues related to the earth and all natural resources contained on the surface or in the bowels of the earth. Terms of dispute and conflict over land is often used as a synonym considered to have the same meaning. But in fact the two terms that have different characteristics. Under the Head of BPN

\footnotetext{
${ }^{1}$ Student of Masters (S2) of Law Faculty of Law Unissula Semarang email sigitprihanto.59b@gmail.com

${ }^{2}$ Lecturer of Faculty of Law UNISSULA
} 
Regulation No. 3 of 2011 on the Management Assessment and Case Management of Land, the National Land Agency impose a limit on disputes, conflicts or land case. Head of BPN Regulation Article 1 states that the land is disputed cases.

Land disputes are land disputes between natural persons, legal entities or institutions that do not have a wide impact socio-political. Emphasis wide impact is what distinguishes the definition of land disputes with the definition of the land conflict. Disputes over land can be administrative disputes, civil disputes, criminal disputes relating to ownership, transactions, registration, underwriting, utilization, tenure and customary rights disputes. Conflict over land is a land dispute between an individual, group, class, organization, corporation or institution that has a tendency or have a broad impact in socio-political.

Land is land dispute case with settlement carried out by the judiciary or judicial ruling which is still awaiting for the handling of the dispute in BPN RI.

Conflicts arising from land disputes that the object is not only resulted in disputes in the field of civil law, but also can occur in the field of administrative law and criminal law.

Looking at the above description, the subject matter of this article is how legislative policy in handling the criminal case related to the land?

\section{Results And Discussion}

In general offenses in the Criminal Code relating to land when seen in terms of time, the crime of land can be divided into:

- Pre-Financial, as contained in:

- Article 385 of the Criminal Code

Punishable by a maximum imprisonment of four years:

- Whoever with the intent of enriching himself or another person unlawfully, sell, exchange or encumber with creditverband something land rights that have been certified, something the building, building, planting or seeding on land that has not been certified, but note that that have or participate have a right on it is another person;

- whoever with the same intent to sell, exchange or encumber with credietverband, something that has not been certified land rights that have been dibehani credietverband or anything buildings, planting or seeding on land that has also been burdened so, without informing them of their Heban that the other party;

- whoever with the same intent to hold land rights credietverband about something that has not been certified, by hiding the other side that the land relating to the rights had already mortgaged;

- whoever with the same intent, mortgage or lease land with land rights that have not been certified yet known that other people who have or have helped the land rights;

- whoever with the same intent, sell or exchange the land with the land rights that have not been certified already mortgaged, but he had not shared the other party that the land has been mortgaged;

- whoever with the same intent to sell or exchange the land with the land rights that have not been certified for a period, when known, that the land had been leased to others for the future as well. 
- Article 389 of the Criminal Code

Whoever with the intent to benefit themselves or others unlawfully, destroy, remove, dispose of or make unusable something that is used to determine the limits of its lands, punishable by a maximum imprisonment of two years and eight months.

- Article 263 of the Criminal Code

- Anyone who makes a false letter or forged which can give rise to a right, commitment or debt relief, or which is applied as evidence rather than something with the intent to use or have someone else wear the letter as if it was true and not doctored, threatened that if the use of can cause a loss, because of forgery, with a maximum imprisonment of six years.

- Punishable by the same person who deliberately wear a false or forged letter as if true, if the use of the letter can result in losses.

- Article 264 of the Criminal Code

- Forgery punishable by a maximum imprisonment of eight years, if committed against: a) authentic or legitimate documents; b) debentures or certificate of indebtedness of a country or part thereof, or of a public institution; c) letter or certificate stock or debt holdings or debts of an association, institution, company or airline; d) talon, receipt of dividends or interest from one of the letters described in 2 and 3, or proof issued in lieu of letters; e) letter of credit or letter of trade destined for circulation.

- Punishable by the same person who deliberately put the letter in the first paragraph, the contents of which are not genuine or faked as if true and not doctored, if forgery that may cause harm.

- Article 266 of the Criminal Code

- Anyone who tells insert false information into an authentic act about something whose truth must be declared by a deed that, with a view to taking or have someone else wear the deed was as if his statement in accordance with the truth, threatened, if the use of it can cause harm, with a maximum imprisonment of seven years;

- Punishable by the same person who deliberately put the letter in the first paragraph, the contents of which are not genuine or faked as if true and not doctored, if forgery that may cause harm.

- Master without rights, as contained in Article 425 of the Criminal Code, which reads:

Threatened for extortion by a maximum imprisonment of seven years:

- an official in the exercise of duties, soliciting, accepting or cut payments, as though indebted to him, to other authorities or to the public treasury, but knew that was not so;

- an official in the exercise of duties, solicit or accept the job or delivery of goods as if is owed to him, but he knew that was not the case;

- an official in the exercise of duties, as if in accordance with the relevant rules have been using public land on which there are rights of Indonesian life at the expense entitled to when he knew that it was against the rules.

- Admitted without rights, contained in:

- Article 167 of the Criminal Code 
- Anyone who forced their way into the house, room or enclosed yard which is used by another person unlawfully, or are there unlawfully, and upon request shall or suruhannya not go immediately, punishable by a maximum imprisonment of nine months or a maximum fine of four thousand five hundred rupiah.

- Whoever entered by damaging or climbing, using false keys, false commands or false jahatan clothing, or anyone who is not entitled to advance knowledge and not because of an oversight entered and found to be in there at night, is considered to force entry.

- If issuing the threat or use tools that can be scary person shall be punishable by a maximum imprisonment of one year and four months.

- The criminal in paragraphs 1 and 3 can be added a third if the person who committed the crime two or more allied.

- Article 168 of the Criminal Code

- Anyone who forced their way into the room for the general service, or are there unlawfully, and at the request of the competent authority does not go away immediately, threatened with imprisonment for a period of four months and two weeks or a maximum fine of four thousand five hundred rupiah ,

- Whoever entered by damaging or climbing, using false keys, false orders, or apparel false positions, or anyone who is not the knowledge of the competent authorities in advance and not because of an oversight entered and found to be in there at night, is considered to force entry.

- When he issued the threat or use tools that can be a scary person, is punishable by imprisonment to be the most one year and four months.

- The criminal in paragraphs 1 and 3 can be added a third, if the crimes of two people or more with allied.

In addition, there is more crime in the area of land that is outside the law-undung Book of Criminal Law (Penal Code). as stated in Article 52 of Act No. 5 of 1960 on Basic Regulation of Agrarian. BAL provisions of Article 52 states that:

- Whoever intentionally violates the provisions of Article 15 dipidana with imprisonment of at maximum 3 months and / or

- Government regulations and legislation referred to in Article 19, 22, 24, paragraph (1), $46,47,48,49$, subsection (3) and 50 (2) may provide criminal sanctions for violations of the rules by imprisonment for a maximum 3 months and / or a maximum fine of Rp. 10.000, -

- Criminal offense under subsection (1) and (2) of this article is a violation

Based on the explanation of Article 52 of the BAL, criminal sanctions are necessary to ensure the best implementation of the provisions of the articles. For example, the provisions of Article 15 BAL that every person, legal entity or institution that has relations with the land, with attention to the economically weak berwajiban preserve land, including adding kesuburanya and prevent damage. It is clear that the BAL trying to maintain a balance meeting the needs / interests of society and to individual interests, so that it will achieve the main goal is prosperity, justice and happiness for all people.

Selaian in the foregoing, crimes related to land are also regulated in Law Number 51 of 1960 on the Prohibition PRP Land Use Authorized Or Unauthorized Attorneys. Article 2 of 
Act No. PRP 51 of 1960 states that "it is forbidden to wear land without permission entitled or authorized proxy". If this provision is violated, "may be liable to imprisonment for a maximum 3 (three) months and / or fines of up to Rp. 5.000, - (five thousand rupiah) ", referred to the provisions laid down Article 6.

The provisions of article 6 of Act No. 51 PRP Of 1960 also applies to actions: (1) interfere entitled or authorized proxy in the use rights over a plot; (2) ordering, invite, persuade or encourage orally or in writing to do anything referred to in paragraphs a and b; (3) provide assistance in any way to commit an act referred to in article 2 or the letter $b$.

In the process of enforcing the law against crimes above required a perception among law enforcement officers, the police (investigator), prosecutor (public prosecutor) and judges. The aim is to avoid mistakes both when conducting the investigation, prosecution and criminal punishment. The land conflict that comes from civil relations are very vulnerable at all to do engineering or coercion case that is basically used as a civil dispute dispute the criminal field.

Equations understanding of the substance of a criminal offense before the legal process is necessary for a criminal law enforcement system can function properly. These systems are usually referred by the criminal justice system. According to Romli Atmasasmita, the criminal justice system is the mechanism of action in combating crime by using the basic approach of the system. ${ }^{3}$

The criminal justice system embodied / implemented within four (4) sub-system is the power of investigation, prosecution powers, the power to judge and control the implementation of decisions. ${ }^{4}$ Or in other words, the criminal justice system consists of four components, namely the police, prosecutors, courts and prisons.

Each of these components are expected to work together and can form an integrated criminal justice system. If the system integration in the work is not done, it is estimated there will be three disadvantages, namely: ${ }^{5}$

- difficulty in judging their own success or failure of each institution, in connection with their duties together

- difficulty in solving its own problems in each institution subject (as a subsystem of the criminal justice system)

- because the responsibilities of each agency is often less clearly divided, then each istansi little attention to overall effectiveness of the criminal justice sestem.

In general, the purpose of the criminal justice system as proposed by Mardjono Reksodiputro are: ${ }^{6}$

- prevent people becoming victims;

- resolve cases of crimes so that people are satisfied that keadiln has been upheld and that bersalh convicted;

- see to it that those who have committed a crime not to repeat the crime.

\footnotetext{
${ }^{3}$ Yesmil Anwar dan Adang 2009 Sistem Peradilan Pidana : Konsep Komponen dan Pelaksanaannya dalam Penegakan Hukum di Indonesia Widya Padjadjaran Bandung p. 34.

${ }^{4}$ Barda Nawawi Arief 2011 Kapita Selekta Hukum Pidana tentang Sistem Peradilan Pidana Terpadu (Integreted Criminal Justice System) Badan Penerbit Universitas Diponegoro p. 35

${ }^{5}$ Mardjono Reksodiputro 1994 Kriminologi dan Sistem Peradilan Pidana Pusat Pelayanan Keadilan dan Pengabdian Hukum Jakarta p. 7

${ }^{6}$ Romli Atmasasmita 1995 Kapita Selekta Hukum Pidana dan Kriminologi Mandar Maju Bandung hlm. 3. Lihat juga di dalam Yesmil Anwar dan Adang Op. Cit p. 35
} 
In contrast to Mardjono Reksodiputro, Muladi divides the goal of the criminal justice system into three (3), namely short-term goals in the form of resocialization criminal, medium-term objectives such as crime prevention and long-term goal is for social welfare. ${ }^{7}$ The aim is coaching offender resocialization of offenders back into the community so that when it has become a good person. The purpose of crime prevention meant to be criminal court decision is expected to prevent the perpetrator to commit the crime, whether mecegah real for the actors, nor can a preventive function for the community in general for not committing a crime. The purpose of social welfare function to protect people from evil deeds very disturbing security and order in society. ${ }^{8}$

At the level of the courts, the Supreme Court as a controller of the judiciary in Indonesia has issued a criminal law policy at the formulation stage, with the enactment of the Supreme Court No. 1 of 1956. There are some things that specified in Perma, namely:

- article 1

If the examination of the criminal case should be decided case the existence of a civil case of an item or of a legal relationship between two specific parties, then the criminal case investigation can dipertangguhkan to wait for a court decision in a civil case examination of the existence or absence of the civil rights.

- Section 2

Deferment of criminal case investigation can be terminated at any time, if deemed no longer necessary.

- Article 3

The court in the criminal case investigation is not bound by a court decision in a civil case examination of the existence or absence of an earlier civil rights.

The provision is essentially affirms that the resolution of the criminal case that still contains a civil dispute, it should first be resolved in its civil dispute. This is with the aim that the error will not occur in deciding the case.

The provisions on the suspension of examination of the criminal case is also contained in the Decision of Cassation Supreme Court No. 628 K / Pid / 1984 dated March 18 1956yang the verdict states that ordered the High Court of Bandung reopen the proceedings and examine and decide upon the subject of this case after the court decision in a civil case which will determine the status of land ownership HGB No. 197 / Penaragan located at Jalan Merdeka No. 11A Bogor has definite strength. The essence of this decision is the Bandung High Court before deciding the principal case of Article 385 paragraph (1) of the Criminal Code should wait first court decision that will determine the status of ownership of land and houses to have a definite strength.

In addition to policies and regulations issued by the Supreme Court, the Attorney General has also issued the policy as contained in the Letter of the Deputy Attorney General for General Crimes No. B-230 / E / EJP / 01/2013 dated January 22, 2013 regarding Case Management General Crimes that Object Form Land. In this letter explained that the criminal case handler object common form of land showed increasing trend and escalation. That the case with the land object is a prospective business area and so it is potentially lucrative land cases mounted by various interests, both among individual

\footnotetext{
${ }^{7}$ Muladi 1995 Kapita Selekta Sistem Peradilan Pidana BP Undip Semarang p. vii

${ }^{8}$ Setya Wahyudi 2011 Implementasi Ide Diversi dalam Pembaharuan Sistem Peradilan Pidana Anak di Indonesia Genta Publishing Yogyakarta p. 37-38
} 
elements, land mafia and a case broker. There are indications in cases where land is supposed to civil imposed and engineered into a criminal case with the use of Article 170, $263,266,378$,

In the letter explained if ever the case that the object is in the form of land, where the legal status of land ownership on the lands of the rights owned, clear, strong and legitimate in accordance with the provisions of the law, then if there are those who violate them, for example in the form of land grabbing, then the case can criminalized. But otherwise, if ever the case that the object is in the form of land unclear legal status of ownership, so that becomes the object of civil disputes, as well as disputes in land transactions where the legal status of ownership has been owned by the seller, the next there is a dispute in the sale and purchase transactions land is concerned, the case is within the realm of civil and is a purely civil matters, so it should not be forced to herded into the realm of general crime.

Furthermore, when dealing with a case that the object is in the form of land, where there are civil lawsuits on goods (land) or on a legal relationship (buying and selling) between two (2) a particular party, then the criminal case mumum concerned may be deferred / pending and waiting outusan court in a civil case with mempedomi provisions:

- Article 81 of the Criminal Code

- Supreme Court Regulation No. 1 of 1956

- Supreme Court Circular No. 4 of 1980

- Supreme Court Decision Number 413 / K / KR / 1980 dated August 26, 1980 Jo. Supreme Court Decision Number 129K / Cr / 1979 dated 16 April 1980 Jo. Supreme Court Decision Number 628K / Pid / 1984 dated July 22, 1985

Both regulations issued by the Supreme Court and the Attorney General at the top of a step taken to prevent manipulation or coercion cases conducted by elements of selfinterest. The provision is not omit examination of criminal cases related to land that still has a civil dispute, but rather the menagguhkan examination in order to avoid errors / mistakes in mengambik decisions in the criminal justice system.

In the hands of police who has authority investigating all offenses (including crimes related / berobjekkan land) there are no regulations governing policies as stipulated in Perma No. 11956 and Letter Edara Junior Attorney General Piana No. B-230 2013. In fact, the police investigator is the gate of the criminal case investigation. Although at the investigator level there are no provisions on the suspension of the criminal case investigation related to the land, but the investigators are able to make both the regulatory policies above as a guide in the handling of the investigation of criminal offenses relating to the land. This is done in order to avoid bottlenecks in the handling of cases and for the realization of an integrated criminal justice system.

\section{CLOSING}

\subsection{Conclusion}

Handling the criminal case related to the land should be done carefully and cautiously through the understanding of the anatomy of the case and from the evidence of civil owned by the parties. It aims to prevent the engineering / coercion case which is basically a pure civil dispute, eventually used as criminal assault. To deal with this phenomenon, the Supreme Court has issued a Supreme Court Regulation No. 1 of 1956 and the 
jurisprudence of the Supreme Court No. 628K / Pid / 1984. So also in the Attorney General's Office has issued a Circular Letter of the Attorney General for General Crimes, No. B-230 / E / EJP / 01/2013 dated January 22, 2013. While in the police has been no regulatory policies relating thereto.

\subsection{Suggestion}

It is recommended that in the Police made the regulatory policies that govern the handling of criminal case that berobjekkan land, causing the synchronization / harmonization of laws between the policies issued by the Supreme Court (Judge), General Attorney and Police (investigators). It aims to provide legal certainty in the handling of the case. The policy can be made in the form of a new Police Regulation or inserted in the Police Regulation No. 14 Of 2012 concerning the Crime Investigation Management or in the form Telegram Head of Criminal Investigation (TR Kabareskrim).

\section{Bibliography}

[1] Anwar Yesmil dan Adang 2009 Sistem Peradilan Pidana : Konsep Komponen dan Pelaksanaannya dalam Penegakan Hukum di Indonesia Widya Padjadjaran Bandung

[2] Arief Barda Nawawi 2011 Kapita Selekta Hukum Pidana tentang Sistem Peradilan Pidana Terpadu (Integreted Criminal Justice System) Badan Penerbit Universitas Diponegoro

[3] Atmasasmita Romli 1995 Kapita Selekta Hukum Pidana dan Kriminologi Mandar Maju Bandung

[4] Muladi 1995 Kapita Selekta Sistem Peradilan Pidana BP Undip Semarang

[5] Reksodiputro Mardjono Kriminologi dan Sistem Peradilan Pidana Jakarta: Pusat Pelayanan Keadilan dan Pengabdian Hukum 1994

[6] Wahyudi Setya Implementasi Ide Diversi dalam Pembaharuan Sistem Peradilan Pidana Anak di Indonesia Yogyakarta: Genta Publishing 2011

[7] Book of the Criminal Justice Act

[8] Act No. 5 of 1960 on Basic Regulation Agrarian

[9] Act No. 51 of 1960 on the Prohibition PRP Land Use Permit Authorized Or Without Proxy

[10] Regulation of the National Land Agency No. 3 Of 2011 on the Management of the Assessment and Management of Land Cases

[11] Supreme Court Regulation No. 1 of 1956 dated March 181956

[12] Supreme Court Decision Number 628K / Pid / 1984 dated July 221985

[13] Circular of the Attorney General for General Crimes No. B-230 / E / EJP / 01/2013 dated January 222013 